\title{
PENERAPAN MODEL PEMBELAJARAN PROBLEM SOLVING BERBANTUAN METODE PEER TUTORING UNTUK MENINGKATKAN KEMAMPUAN BERPIKIR KRITIS DAN PRESTASI BELAJAR SISWA PADA MATERI STOIKIOMETRI KELAS X MIA 3 SMA BATIK 2 SURAKARTA TAHUN PELAJARAN 2015/ 2016
}

\author{
Tuti Prihatinah ${ }^{*}$, Haryono, dan Budi Utami \\ Program Studi Pendidikan Kimia, FKIP,Universitas Sebelas Maret, Surakarta, Indonesia \\ *Keperluan korespondensi, telp: 082313235440, email: tutiprihatina25@gmail.com
}

\begin{abstract}
ABSTRAK
Penelitian ini bertujuan untuk meningkatkan kemampuan berpikir kritis dan prestasi belajar pada materi stoikiometri untuk siswa kelas X MIA 3 SMA Batik 2 Surakarta melalui penerapan model pembelajaran Problem Solving berbantuan metode Peer Tutoring. Penelitian ini merupakan Penelitian Tindakan Kelas (PTK) yang dilaksanakan dalam dua siklus. Subjek penelitian ini adalah siswa kelas X MIA 3 SMA Batik 2 Surakarta tahun pelajaran 2015/2016. Teknik pengumpulan data melalui observasi, angket, wawancara, kajian dokumen, dan tes. Teknik analisis yang digunakan adalah deskriptif kualitatif. Hasil penelitian menunjukkan bahwa penerapan model pembelajaran Problem Solving berbantuan metode Peer Tutoring dapat meningkatkan kemampuan berpikir kritis dan prestasi belajar pada materi stoikiometri untuk siswa kelas X MIA 3 SMA Batik 2 Surakarta. Siswa yang memiliki kemampuan berpikir kritis dengan kategori tinggi dan sangat tinggi pada siklus I sebesar $84,62 \%$, sedangkan pada siklus II sebesar $92,31 \%$. Untuk prestasi belajar pada kompetensi pengetahuan, capaian ketuntasan pada siklus I sebesar $46,15 \%$ dan pada siklus II meningkat menjadi 76,92\%. Pada kompetensi sikap diperoleh ketercapaian sebesar $100 \%$ siswa bersikap baik dan sangat baik. Pada kompetensi keterampilan, diperoleh ketercapaian $97,44 \%$ siswa tuntas.
\end{abstract}

Kata kunci: Problem solving, peer tutoring, kemampuan berpikir kritis, prestasi belajar, stoikiometri

\section{PENDAHULUAN}

Pembelajaran merupakan proses interaksi antarpeserta didik dan antara peserta didik dengan pendidik dan sumber belajar pada suatu lingkungan belajar [1]. Peserta didik disini adalah siswa dan guru sebagai pendidiknya. Melalui proses pembelajaran, guru dapat mengetahui kemampuan dasar yang dimiliki oleh siswa yang meliputi kemampuan dasar, motivasi, latar belakang akademis, latar belakang ekonomi, dan sebagainya. Kesiapan guru untuk mengenal karakteristik siswa dalam pembelajaran merupakan modal utama dalam penyampaian bahan belajar dan menjadi indikator suksesnya pelakasanaan pembelajaran.
Materi pembelajaran merupakan salah satu komponen pembelajaran penting yang terangkum dalam setiap mata pelajaran. Materi stoikiometri merupakan salah satu contoh materi kimia di SMA yang dianggap sulit untuk dipelajari dan dipahami. Karakteristik materi stoikiometri adalah bersifat riil dan perlu menggabungkan antara pemahaman konsep dan aplikasi. Materi ini membutuhkan pemahaman konsep yang baik dan kemampuan berpikir kritis yang tinggi dalam penyelesaian soal-soalnya. Biasanya siswa mengalami kesulitan dalam mengerjakan soal-soal perhitungan kimia, terutama yang berhubungan dengan penggunaan konsep mol. selain itu, Siswa juga 
kesulitan memahami konsep yang mengakibatkan tidak bisa mengapikasikannya ketika menjawab soal. Siswa kesulitan memahami langkahlangkah dalam menyelesaikan persamaan reaksi. Siswa juga kesulitan membedakan rumus dalam perhitungan kimia sehingga tidak bisa mengaplikasikannya dalam menjawab soal.

Salah satu indikator yang menunjukkan bahwa mata pelajaran kimia terkesan sulit adalah prestasi belajar siswa pada materi stoikiometri belum memuaskan. Berdasarkan hasil wawancara dengan guru mata pelajaran kimia SMA Batik 2 Surakarta kelas $X$ tahun pelajaran $2015 / 2016$, disampaikan bahwa pemahaman siswa terhadap materi stoikiometri masih rendah dibandingkan materi yang lain. Hal ini dapat dilihat dari tingkat ketuntasan materi stoikiometri tahun pelajaran 2014/2015 yakni $37,40 \%$ dari 110 siswa dengan Kriteria Ketuntasan Minimal (KKM) 2,67 disajikan pada Tabel 1.

Tabel 1. Ketuntasan Belajar Siswa pada Materi Stoikiometri Tahun Pelajaran 2014/2015

\begin{tabular}{lcc}
\hline Kelas & $\begin{array}{c}\text { Ketuntasan } \\
(\%)\end{array}$ & Rata-rata \\
\hline X MIA 1 & 39,39 & 2,52 \\
X MIA 2 & 41,25 & 2,42 \\
X MIA 3 & 31,57 & 2,36 \\
\hline
\end{tabular}

Menurut hasil wawancara dengan guru mata pelajaran kimia di SMA Batik 2 Surakarta, kelas X MIA 3 memiliki nilai prestasi yang lebih rendah jika dibandingkan dengan dengan kelas $X$ MIA yang lain. Hal ini dapat diketahui berdasarkan nilai ulangan harian maupun nilai ulangan semester ganjil tahun pelajaran 2015/2016 yang menunjukkan bahwa nilai rata-rata siswa kelas X MIA 3 berada di bawah kelas X MIA yang lain. Berdasarkan alasan tersebut, peneliti melakukan observasi lebih lanjut pada kelas X MIA 3 di SMA Batik 2 Surakarta. Setelah dilakukan observasi, dapat diidentifikasi permasalahan-permasalahan yang ada pada kelas tersebut, antara lain pembelajaran pada kelas tersebut masih berpusat pada guru sehingga kurangnya interaksi selama pembelajaran yang menimbulkan kejenuhan pada siswa.

Berdasarkan permasalahan nyata yang terjadi di kelas X MIA 3 SMA Batik 2 Surakarta perlu dilakukan suatu penelitian yang bertujuan untuk memperbaiki masalah pembelajaran yang ada di kelas tersebut. Salah satu upaya untuk mengatasi permasalahan tersebut adalah dengan menerapkan model pembelajaran Problem Solving berbantuan metode Peer Tutoring. Problem Solving merupakan belajar melalui pemecahan masalah dimana tipe belajar seperti ini dapat membentuk prilaku melalui kegiatan pemecahan masalah [2]. Model pembelajaran ini merangsang siswa untuk berpikir kritis dan berorientasi pada permasalahan. Melalui model pembelajaran Problem Solving, siswa akan saling berinteraksi dalam kelompok diskusinya untuk mengklarifikasi dan mengelaborasi ide/gagasan guna memecahkan permasalahan yang sedang dihadapi dalam forum diskusi kelas [3].

Beberapa penelitian sudah dilakukan untuk menerapkan model pembelajaran Problem Solving. Terbukti model pembelajaran Problem Solving dapat menghasilkan prestasi belajar matematika yang lebih baik dibandingkan dengan kelas yang menerapkan model konvensional [4]. Penerapan Problem Solving juga mampu merubah prestasi dan sikap siswa di dalam pembelajaran kimia secara positif [5]. Model pembelajaran ini cocok untuk untuk siswa dengan kemampuan kognitif termasuk dalam kemampuan menalar/ berpikir logis yang tinggi [6]. Adanya peningkatan kemampuan berpikir kritis matematis siswa yang diajarkan dengan model pembelajaran Problem Solving dibandingkan dengan model pembelajaran konvensional [7]. Penerapan Problem Solving dapat meningkatkan prestasi belajar dan aktivitas belajar kimia. Implementasi model pembelajaran Problem Solving berbantuan dengan Peer Tutoring yang dilengkapi dengan hierarki konsep dapat meningkatkan kualitas proses dan hasil belajar pada materi stoikiometri [8]. Dari penelitian tersebut dapat disimpulkan adanya 
pengaruh yang positif antara kemampuan berpikir kritis terhadap prestasi belajar siswa.

Penerapan metode pembelajaran Peer Tutoring dalam pembelajaran kimia di kelas juga telah banyak dilaporkan. Pembelajaran dengan tutor sebaya (Peer Tutoring) adalah suatu metode pembelajaran yang dilakukan dengan cara memberdayakan siswa yang memiliki daya serap tinggi dari kelompok siswa itu sendiri untuk menjadi tutor bagi temantemannya [9]. Referensi lain menyatakan bahwa pembelajaran teman sebaya adalah metode pembelajaran/ instruksi yang diberikan oleh siswa terhadap teman-temannya sendiri di bawah pengawasan guru [10].

Peer Tutoring mampu meningkatkan pemahaman siswa terhadap prinsipprinsip dalam penerapan ilmu pada pembelajaran kimia dalam kelompok [11]. Metode ini juga mampu menimbulkan suasana yang kolaboratif antar siswa sehingga tercipta kerja sama yang efektif dalam satu kelompok. Penerapan metode Peer Tutoring juga meningkatkan prestasi belajar siswa pada materi redoks dan elektrokimia[12]. Melalui tutor sebaya diharapkan akan terbangun perilaku potensial melalui pengorganisasian materi pembelajaran di kelas secara mandiri dalam bentuk mencari pertolongan selama proses belajar berlangsung secara lebih intensif karena adanya jarak psikologis yang minimal antara tutor dan tutee.

Berdasarkan latar belakang yang telah diuraikan di atas, perlu dilakukan penelitian tentang "Penerapan Model Pembelajaran Problem Solving Berbantuan Metode Peer Tutoring untuk Meningkatkan Kemampuan Berpikir Kritis dan Prestasi Belajar Siswa pada Materi Stoikiometri Kelas X MIA 3 SMA Batik 2 SurakartaTahun Pelajaran 2015/2016".

\section{METODE PENELITIAN}

Penelitian ini merupakan Penelitian Tindakan Kelas (PTK) yang dilakukan selama 2 siklus, dimana masing-masing siklus terdiri dari tahap: perencanaan, pelaksanaan, pengamatan, dan refleksi
[13]. Subjek penelitian adalah siswa kelas X MIA 3 semester genap SMA Batik 2 Surakartai tahun pelajaran 2015/2016 yang berjumlah 39 siswa. Pemilihan subjek dalam penelitian ini didasarkan pada pertimbangan bahwa subjek tersebut mengalami permasalahan yang telah teridentifikasi pada saat observasi awal. Objek penelitian ini adalah kemampuan berpikir kritis dan prestasi belajar siswa terhadap pembelajaran yang diterapkan.

Sumber data berasal dari siswa, observer, dan guru selama proses kegiatan pembelajaran. Pengumpulan data dilakukan dengan teknik angket, observasi, tes, dokumentasi, dan wawancara. Teknik analisis data berupa analisis deskriptif kualitatif yang berpedoman pada model analisis Miles dan Huberman yang dilakukan dalam 3 tahap yaitu: reduksi data, sajian data, dan penarikan kesimpulan. Untuk menjaga kevalidan data dalam penelitian digunakan teknik triangulasi data [14].

Indikator keberhasilan proses dan ptestasi belajar disajikan pada Tabel 2 .

Tabel 2. Indikator Keberhasilan Proses dan Prestasi Belajar

\begin{tabular}{lcl}
\hline Kompetensi & \multicolumn{1}{l}{$\begin{array}{l}\text { Target } \\
(\%)\end{array}$} & Kategori \\
\hline KBK & $70 \%$ & T dan ST \\
Pengetahuan & $65 \%$ & Tuntas KKM \\
Sikap & $75 \%$ & B dan SB \\
Keterampilan & $70 \%$ & Tuntas KKM \\
\hline
\end{tabular}

Keterangan:

$\mathrm{KBK}=$ Kemampuan Berpikir Kritis

$\mathrm{T} \quad=$ Tinggi

ST = Sangat Tinggi

$\mathrm{B} \quad=$ Baik

$\mathrm{SB} \quad=$ Sangat Baik

\section{HASIL DAN PEMBAHASAN}

\section{Siklus I}

\section{a. Perencanaan Tindakan}

Pada tahap perencanaan tindakan ini dilakukan penyusunan instrumen pembelajaran berupa silabus RPP. Instrumen penilaian berupa tes kemampuan berpikir kritis, pengetahuan, lembar observasi dan angket penilaian 
sikap, serta keterampilan. Siklus I terdiri dari 4 pertemuan, dimana 3 pertemuan untuk penyampaian materi, dan 1 pertemuan untuk tes siklus I. Alokasi waktu untuk setiap pertemuan adalah 2x45 menit.

\section{b. Pelaksanaan Tindakan}

Pelaksanaan tindakan pada siklus I diawali dengan guru menjelaskan tentang penerapan model pembelajaran Problem Solving berbantuan metode Peer Tutoring. Kemudian siswa dipersilakan membentuk 9 kelompok heterogen (4-5 orang) sesuai dengan pembagian kelompok yang telah ditentukan. Setelah siswa menempatkan diri dalam kelompok, guru memberikan materi pada pertemuan sebelumnya dan mengaitkan dengan materi yang akan disampaikan. Pada bagian orientasi, guru menjelaskan tujuan dan motivasi mempelajari materi tersebut.

Pembelajaran dilaksanakan sesuai dengan sintaks pada Problem Solving yang disesuaikan dengan metode Peer Tutoring. Pada tahap menganalisis masalah, siswa dan kelompok diskusinya dihadapkan dengan permasalahan seputar stoikiometri. Kemudian siswa dengan posisi tutor memandu diskusi untuk mendiagnosis masalah yang diberikan. Kemudian mengambil keputusan untuk menentukan pemecahan masalah dari berbagai alternatif sebelumnya. Langkah terakhir adalah mengevaluasi keberhasilan strategi dengan cara evaluasi pemecahan masalah bersama melalui presentasi dan dilanjutkan dengan guru memberikan konfirmasi terhadap pembelajaran.

\section{c. Pengamatan Tindakan}

Pada pertemuan ini, siswa cenderung masih pasif karena baru pertama kali menerapkan model pembelajaran Problem Solving berbantuan metode Peer Tutoring pada pembelajaran kimia. Setelah beberapa kali pertemuan, siswa menjadi lebih aktif dan antusias selama kegiatan pembelajaran. Hal ini ditandai dengan siswa terlihat aktif mengemukakan pendapat mereka dalam kelompok. Pada saat diskusi kemampuan berpikir kritis siswa semakin meningkat karena siswa didorong untuk menemukan pemecahan masalah. Siswa juga mulai terlatih dalam membuat keputusan secara bersamasama untuk memutuskan jawaban apa yang sesuai dengan permasalahan, penggunaan rumus-rumus yang tepat dan dapat membuat kesimpulan berdasarkan hasil diskusi mereka.

Guru memberikan tes untuk menilai proses dan prestasi belajar siswa. Proses belajar dinilai dengan tes kemampuan berpikir kritis sejumlah 20 soal. Prestasi belajar pada kompetensi pengetahuan berupa 20 soal objektif. Penilaian sikap melalui observasi selama proses pembelajaran, wawancara dengan guru, dan angket penilaian sikap sejumlah 20 pernyataan. Penilaian keterampilan dilakukan sebagai nilai tugas di akhir pertemuan.

Adapun hasil tindakan siklus I untuk keempat kompetensi di atas disajikan pada Tabel 3.

Tabel 3. Hasil Tindakan Siklus I

\begin{tabular}{lcc}
\hline Kompetensi & $\begin{array}{c}\text { Ketercapaian } \\
(\%)\end{array}$ & Ket. \\
\hline KBK & 84,61 & $\mathrm{~T}$ \\
Pengetahuan & 46,15 & $\mathrm{BT}$ \\
Sikap & 100 & $\mathrm{~T}$ \\
Keterampilan & 97,44 & $\mathrm{~T}$ \\
\hline
\end{tabular}

Keterangan:

$\mathrm{KBK}=$ Kemampuan Berpikir Kritis

$\mathrm{T}=$ Tercapai

BT = Belum Tercapai

\section{d. Refleksi}

Berdasarkan Tabel 3, diketahui bahwa kompetensi pengetahuan belum mencapai target ketercapaian indikator penilaian yang ditentukan. Jika dianalisis ketercapaian tiap indikator, maka kemampuan berpikir kritis juga belum sepenuhnya tercapai. Di samping itu, siswa dengan kategori sikap sangat baik masih tergolong sedikit. Untuk penilaian keterampilan sudah mencapai target ketercapaian. Berdasarkan analisis tindakan, peneliti dan guru melakukan diskusi untuk memperbaiki proses pembelajaran dan membuat perencanaan siklus II. Pembelajaran pada siklus II 
membahas indikator yang belum tercapai pada tes kemampuan berpikir kritis, pengetahuan, dan sikap.

\section{Siklus II}

\section{a. Perencanaan Tindakan}

Siklus II dilakukan dalam 2 kali pertemuan. Pertemuan pertama untuk menyampaikan materi dan pertemuan kedua untuk tes siklus II. Tahap ini diawali dengan penyusunan instrumen pembelajaran berupa RPP sebagai perbaikan pada siklus I. Instrumen penilaian berupa tes kemampuan berpikir kritis, tes pengetahuan, dan angket penilaian sikap.

Pada siklus II ini menggunakan kelompok yang sama dengan siklus I. Siswa yang sudah tuntas pada penilaian kompetensi pengetahuan dijadikan sebagai tutor selama diskusi berlangsung. Perbedaan pada siklus II dengan siklus I adalah setiap kelompok mempunyai lebih dari satu orang tutor. Siklus II ini juga terfokus pada indikator soal yang belum tuntas. Selama kegiatan pembelajaran siswa banyak berlatih menyelesaikan permasalahan seputar stoikiometri, yaitu : menentukan pereaksi pembatas, menghitung kadar zat, serta menentukan rumus empiris dan rumus molekul.

\section{b. Pelaksanaan Tindakan}

Pelaksanaan tindakan pada siklus II difokuskan untuk memperbaiki kekurangan yang ada pada siklus I. Guru juga lebih terfokus pada siswa yang mengalami banyak kesulitan pada kompetensi pengetahuan. Selama pembelajaran siklus II, masih dilakukan pengamatan terhadap sikap siswa melalui lembar observasi dan wawancara dengan guru. Pada siklus II tidak dilakukan lagi penilaian pada kompetensi keterampilan. Jadi hasil penilaian keterampilan diperoleh berdasarkan hasil penilaian pada siklus I.

Pada pertemuan siklus II diawali dengan apersepsi, yaitu guru mengulang sekilas materi yang berhubungan dengan pelajaran yang akan disampaikan hari ini, selanjutnya guru menginformasikan tujuan pembelajaran pada pertemuan tersebut dan memberikan motivasi pada siswa.

Pada tahap menganalisis masalah, siswa dan kelompok diskusinya dihadapkan dengan permasalahan seputar stoikiometri. Kemudian siswa dengan posisi tutor memandu diskusi untuk mendiagnosis masalah yang diberikan. Bertambahnya jumlah tutor pada siklus II diharapkan dapat memberikan perbaikan pada proses pembelajaran di siklus II ini. Kemudian mengambil keputusan untuk menentukan pemecahan masalah dari berbagai alternatif sebelumnya. Langkah terakhir adalah mengevaluasi keberhasilan strategi dengan cara evaluasi pemecahan masalah bersama melalui presentasi dan dilanjutkan dengan guru memberikan konfirmasi terhadap pembelajaran.

\section{c. Pengamatan Tindakan}

Kemampuan berpikir kritis siswa semakin meningkat pada siklus II. Hal ini ditandai dengan siswa mulai bisa menarik kesimpulan berdasarkan faktafakta yang diberikan. siswa mulai terlatih dalam memecahkan masalah yang diberikan selama diskusi bersama kelompoknya. selain itu, penguasaan materi stoikiometri pada siklus II semakin meningkat.

Pada akhir siklus, guru memberikan tes untuk siklus II. Penilaian kemampuan berpikir kritis berupa soal objektif sejumlah 20 soal. Penilaian kompetensi pengetahuan berupa soal objektif sejumlah 15 soal. Angket penilaian sikap sejumlah 20 pernyataan.

Adapun hasil tindakan siklus II untuk ketiga kompetensi di atas disajikan pada Tabel 4.

Tabel 4. Hasil Tindakan Siklus II

\begin{tabular}{lcc}
\hline Kompetensi & \multicolumn{2}{l}{ Ketercapaian } \\
$(\%)$ & Ket. \\
\hline KBK & 92,31 & $\mathrm{~T}$ \\
Pengetahuan & 71,46 & $\mathrm{~T}$ \\
Sikap & 100 & $\mathrm{~T}$ \\
\hline
\end{tabular}

Keterangan:

$\mathrm{KBK}=$ Kemampuan Berpikir Kritis

$\mathrm{T} \quad=$ Tercapai 


\section{d. Refleksi}

Berdasarkan Tabel 4, diketahui bahwa semua kompetensi telah tuntas di siklus II. Pada penelitian ini, terjadi peningkatan prestasi belajar dari siklus I ke siklus II. Hasil ketercapaian tiap siklus untuk masing-masing kompetensi disajikan pada Gambar 1.

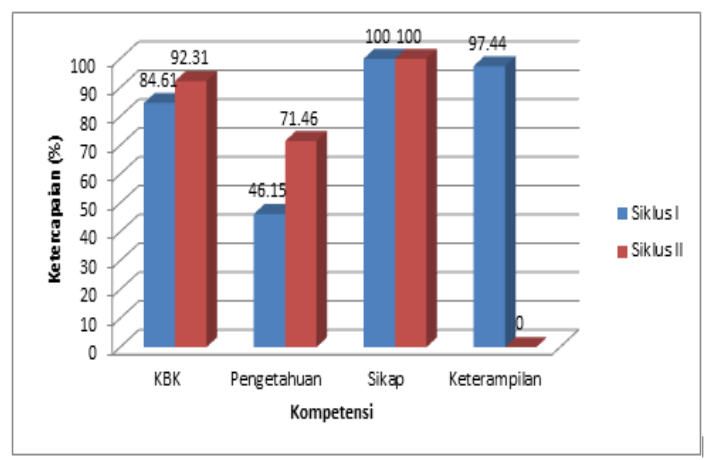

Gambar 1. Ketercapaian Kompetensi Tiap Siklus

Berdasarkan Gambar 1, terlihat peningkatan ketercapaian dari keempat kompetensi yang diukur. Pada penilaian kemampuan berpikir kritis terjadi peningaktan sebesar 7,7\% siswa dengan kategori kemampuan berpikir kritis tinggi dan sangat tinggi. Pada siklus I masih ada 3 indikator soal yang belum mencapai ketuntasan. Pada siklus II semua indikator soal telah mencapai ketuntasan.

Untuk penilaian prestasi belajar kompetensi pengetahuan pada siklus II mengalami peningkatan sebesar $30,77 \%$. Pada siklus I, masih ada 3 indikator soal yang belum mencapai ketuntasan. Pada siklus II semua indikator soal telah mencapai ketuntasan.

Untuk kompetensi sikap tidak terjadi peningkatan pada siklus II. Ketercapaian pada kompetensi sikap sudah mencapai $100 \%$. Perbedaan antara siklus I dan siklus II adalah jumlah siswa dengan kategori sikap baik dan sangat baik. Pada siklus I siswa dengan kategori sikap baik sebesar $89,74 \%$ dan kategori sangat baik sebesar 10,26\%. Pada siklus II siswa dengan kategori sikap baik sebesar $66,67 \%$ dan kategori sangat baik sebesar $33,33 \%$.
Untuk kompetensi keterampilan hanya dilakukan pada siklus I dan sudah diperoleh hasil yang maksimal, yaitu 97,44\%. Pada siklus II tidak dilakukan lagi penilaian terhadap kompetensi keterampilan. Maka dari itu evaluasi pada siklus II difokuskan pada kompetensi kemampuan berpikir kritis, pengetahuan, dan sikap.

\section{KESIMPULAN}

Berdasarkan hasil penelitian dan pembahasan yang telah diuraikan di atas, maka dapat ditarik kesimpulan bahwa penerapan model pembelajaran Problem Solving berbantuan metode Peer Tutoring dapat meningkatkan kemampuan berpikir kritis dan prestasi belajar siswa pada materi stoikiometri untuk siswa kelas X MIA 3 SMA Batik 2 Surakarta tahun pelajaran 2015/2016.

Pada siklus I siswa dengan kategori kemampuan berpikir kritis tinggi dan sangat tinggi sebesar $84,61 \%$, sedangkan pada siklus II sebesar $92,31 \%$. Peningkatan prestasi siswa pada kompetensi pengetahuan siklus I ketuntasan siswa sebesar 46,15\% meningkat menjadi $76,92 \%$ pada siklus II. Pada kompetensi sikap siklus I, siswa dengan kategori sikap baik dan sangat baik sudah mencapai ketuntasan 100\%. Pada kompetensi keterampilan siklus I, 97,44\% siswa sudah mencapai ketuntasan.

\section{UCAPAN TERIMA KASIH}

Bapak Drs. Soewarto, M.M. selaku kepala sekolah SMA Batik 2 Surakarta yang telah memberikan izin penelitian, Bapak Ispriyanto, M.Pd. selaku guru mata pelajaran kimia di kelas X MIA yang telah memberikan izin kelasnya digunakan untuk penelitian, siswa kelas $X$ MIA 3 dan semua pihak yang turut berperan dalam penelitian ini.

\section{DAFTAR RUJUKAN}

[1] Permendikbud, 2013, Peraturan Menteri Pendidikan dan Kebudayaan No 103 Tahun 2014 tentang Pembelajaran pada Pendidikan Dasar dan Pendidikan Menengah, Jakarta. 
[2] Pait, I. M., 2012, Skripsi tidak dipublikasikan, Universitas Pendidikan Ganesha, Bali.

[3] Criswell, B. A. dan Rushton, G. T., 2014, Research in Science Education, Vol. 44, 155-188.

[4] Nfon, N. F., 2013, Journal of Mathematic Education, Vol. 6(1), 3855.

[5] Festus, C., \& Ekpete, A. O., 2012, International Journal of Academic Research in Progresive Education and Development, Vol. 1(1). 167174.

[6] Seddigi, Z. S. \& Oveton, T. L., 2003, Chemistry Education: Research and Practice, Vol. 5(3). 387-395.

[7] Fariha, M., 2013, Jurnal Peluang, Vol. 1 (2) 2302-5158.

[8] Arjanggi, R. \& Suprihatin, T., 2010, Jurnal Makara, Sosial Humaniora, Vol. 14(2), 91-97.

Ishartono, B., 2014, Jurnal

[9] Pendidika Kimia, Vol. 4 No. 1 Tahun 2015 Hal.10-19.

[10] Cole, P. G dan Chan, L. K. S., 1990, Methods and Strategies for Special Education, Prentice Hall of Australia Pty Ltd.

[11] Keenan, K., 1980, Kimia Untuk Universitas, Erlangga, Jakarta.

[12] Rahmawati, S., 2007, Prosiding Seminar Nasional Kimia dan Pendidikan Kimia III (SN-KPK III), ISBN 978979153385 0, 88-95.

[13] Arikunto, S, Suhardjono, \& Supardi. (2008). Penelitian Tindakan Kelas. Jakarta: Sinar Grafika.

[14] Sugiono, 2010, Metode Penelitian Pendidikan Pendekatan Kuantitatif, Kualitatif dan R\&D, Alfabeta, Bandung . 